\title{
OUTROS HORIZONTES PARA A PATERNIDADE BRASILEIRA NO SÉCULO XXI?
}

\author{
Ana Liési Thurler*
}

Resumo: Este artigo tem como objetivo analisar a paternidade quanto ao exercício do reconhecimento geracional, com dimensões formallegal e afetivo-social igualmente importantes, que colocam, ao paicidadão, demandas políticas com a perspectiva de uma democracia expandida. Em um e outro nível, o não-reconhecimento paterno de crianças brasileiras é aqui interpretado como a persistência de antigas práticas patriarcais, nas quais o arbítrio masculino foi - e tem se mantido - naturalizado. A superação de relações sociais patriarcais é um imperativo tanto para a efetivação do direito à igualdade de todas as crianças à filiação paterna - nascidas em relações eventuais ou estáveis, no casamento ou fora dele - e para o desenvolvimento da solidariedade como promotora da igualdade de responsabilidades e direitos entre mulheres e homens relativamente à parentalidade, quanto para a abertura de espaços a novas vivências parentais, como a pluriparentalidade e a homoparentalidade.

Palavras-chave: reconhecimento, paternidade, cidadania, práticas paternas.

A interrogação contida no título deste artigo questiona a possibilidade da ocorrência de mudanças nos padrões patriarcais em vigor nas práticas paternas que ainda comportam a possibilidade real de não-reconhecimento da criança pelo pai que deserta, ocorrendo não só a negação de reconhecimento legal, jurídico - que não pode

\footnotetext{
Doutora em Sociologia pela Universidade de Brasília e mestre em Filosofia pela Universidade Federal de Santa Maria, é pesquisadora associada ao Departamento de Sociologia da UnB e integrante do Núcleo de Estudos e Pesquisas sobre a Mulher (NEPeM-UnB). Coordena o Projeto Paternidade e Cidadania nas Escolas, parceria ICS/ UnB e CNTE, que está sendo implementado no Estado do Piauí, com o protagonismo do SINTE-PI.

Recebido em 8 abr. 2006 e aprovado em 22 nov. 2006.
} 
ser secundarizado - mas também pela suspensão, arbitrária e a qualquer tempo, do reconhecimento social e afetivo. ${ }^{1}$

Refiro-me a pais desertores e a crianças somente com a filiação materna estabelecida em seu registro civil de nascimento - quando não é essa a opção da mãe - mantendo-me distante da consternação de Mitscherlich (1969), criador da expressão "sociedade sem pais", que lastimava o fim de uma era da autoridade e do poder do pai, guardião da moralidade patriarcal. ${ }^{2}$ Em minha interpretação, o pai desertor, com suas práticas, não elimina ou encerra a era do patriarca. Somente promove sua reconfiguração.

Transformações significam outros horizontes em que o reconhecimento paterno se vincularia a exercício de cidadania, situando-se fora do campo do arbítrio e da aleatoriedade. Ligandose à cidadania, o reconhecimento paterno coloca implicações sociopolíticas, traduzindo-se em reconhecimento geracional - importante dimensão do reconhecimento -, em compromissos transgeracionais de verticalidade - acolhimento, respeito à descendência, cuidados - e, também, exigências éticas com caráter de horizontalidade - exercício de solidariedade com a mulher-mãe.

\section{Reconhecimento, o outro nome da Justiça}

$\mathrm{O}$ reconhecimento vincula-se à condição de igualdade $\mathrm{e}$ empoderamento de segmentos vulnerabilizados, de auto-estima, solidariedade e redistribuição da Justiça, a melhores padrões de cidadania e de sociabilidade. O conceito vem ganhando maior relevância na filosofia política e nas ciências sociais (Fraser, 2004, 2002; Fraser e Honneth, 2003; Honneth, 2004, 2003; Lazzeri e Caillé, 2004; Mattos, 2004). O investimento em novos padrões culturais fundados no reconhecimento do(s) outro(s) - grupo ou pessoa, envolvendo respeito a diferenças de raça, sexo, orientação sexual, classe, idade, gerações, religiosidades - e na promoção de políticas de reconhecimento afirma-se como imperativo para o aprimoramento da democracia. 
É no quadro das políticas de reconhecimento que se situa a questão da negação de reconhecimento a crianças brasileiras por homens-pais. O reconhecimento paterno tem uma dimensão social e afetiva, e uma dimensão formal - jurídica, legal -, igualmente importantes para o fortalecimento da cidadania da criança, além das cidadanias do próprio pai e da mãe.

Quais as dimensões do não-reconhecimento paterno no Brasil? Dados sobre não-reconhecimento paterno - formal, legal, por meio do estabelecimento da filiação paterna no registro civil de nascimento - não são produzidos no país. Proponho uma estimativa para o nãoreconhecimento formal a partir do exame de 183.618 registros civis de nascimento, realizado nos dez Cartórios de Registros Civis de Pessoas Naturais do Distrito Federal, corrrespondentes aos anos de 1961, 1970, 1980, 1990 e 2000. Nesse universo, 21.991 registros não continham a filiação paterna estabelecida: uma incidência de $12 \%{ }^{4}$ Por outro lado, estavam sem reconhecimento materno 230 desse universo, o que significa uma incidência de $0,12 \%$. O engajamento da mãe é a regra geral, ocorrendo em 99,88\% dos registros Ou seja, para cada 100 pais que não reconheceram sua criança, foi encontrada uma mãe que deixou de fazê-lo (Thurler, 2004).

\section{Maternidade culpabilizada, paternidade protegida: outros horizontes?}

Apesar dessa realidade no estabelecimento do vínculo de mães e pais com a criança, pesquisa realizada entre $1^{\circ}$ de janeiro de 1998 e 30 de junho de 1999 constatou tratamento fortemente desigual dado pela mídia à mãe e ao pai, em casos de abandono de bebês. Analisadas 77 matérias sobre o tema, produzidas e publicadas nesse período de 18 meses pelos dois jornais de circulação diária na capital do país, o Correio Braziliense e o Jornal de Brasília, verificou-se que a identidade dos homens-pais foi protegida e eles receberam tratamento indulgente. As mães sofreram exposições públicas, julgamentos severos e condenações (Thurler, 2001, 2002). 
O exame do tratamento dado a casos ocorridos no Brasil urbano já do século XXI, envolvendo suposta atenção de pais que levariam crianças à escola, mas esquecendo-as no carro, sob o sol, resultando em óbitos, revela acentuada desigualdade de representações sociais ligadas à condição da maternidade e da paternidade. Casos noticiados na imprensa relatam benevolência nas respostas de autoridades, imediatamente justificando e dissociando esses esquecimentos de negligência ou abandono. Verificamos diversas ocorrências dessa ordem: em 13 de abril de 2006, na zona norte de São Paulo, capital, envolvendo o pai e um menino de um ano e três meses; ${ }^{5}$ em 30 de maio de 2000, em Franca (SP), envolvendo o pai e uma menina de um ano e cinco meses; ${ }^{6}$ em 30 de outubro de 1997, envolvendo o pai e uma menina de dez meses, em Ribeirão Preto (SP). ${ }^{7}$

Em situações de abandono de bebês pela mãe, sua responsabilidade e culpa nos acontecimentos tem sido apresentada sem atenuantes. ${ }^{8}$ No caso de morte de bebês por esquecimento pelo pai em carros da família, a responsabilidade desse pai no cuidado com a criança foi pública e unanimemente abrandada por profissionais e autoridades diversas - de saúde, do judiciário, policiais - e pela mídia, que rapidamente retirou o tema de pauta. Nesses episódios de descuido paterno, as crianças - entre dez meses e um ano e cinco meses - foram esquecidas como identidades, desconsideradas como sujeitos do direito à vida, tanto nas manifestações das autoridades, quanto nas matérias veiculadas pela imprensa. $\mathrm{O}$ abandono paterno foi interpretado com clemência. Contrariamente, o embrião no interior do corpo da mulher é pressuposto pela legislação brasileira como sujeito de direito à vida, como um ser humano completo, tangido pelo princípio de intocabilidade. $\mathrm{E}$ a recusa da mulher a dar guarida ao desenvolvimento desse embrião permanece criminalizada.

Manifestações de estranhamento vieram de pessoas anônimas, de internautas. ${ }^{9}$ A perplexidade dessas pessoas e a expectativa de qualidade de cuidados paternos e maternos com a criança sinalizam a possibilidade de desnaturalização de padrões vigentes, que legitimam a escassez de realização de trabalhos parentais pelos homens, com a disseminação de crenças como "pai não sabe mesmo 
cuidar de criança", "se ocupar com criança é coisa de mulher". A perplexidade dessas pessoas anônimas sinaliza a possibilidade de outros horizontes para a paternidade brasileira.

\section{Uma estimativa nacional de não-reconhecimento paterno}

Retomando a incidência de $12 \%$ de não-reconhecimento paterno nos registros civis de nascimento encontrados nos dez Cartórios de Registro de Pessoas Naturais do Distrito Federal em pesquisa realizada no primeiro semestre de $2001,{ }^{10}$ proponho uma estimativa em torno de $25 \%$ para a média anual de nãoreconhecimento paterno no país. ${ }^{11}$ Os indicadores sociais do DF apresentam uma constante: têm melhores resultados, em relação às médias nacionais, conforme podemos observar a seguir.

Tabela 1 - Dados comparativos entre o Brasil e o Distrito Federal - 2004

\begin{tabular}{l|r|c}
\hline \multicolumn{1}{c|}{ Domicílios } & Brasil & Distrito Federal \\
\hline Sem abastecimento de água & $17,8 \%$ & $6,9 \%$ \\
Sem energia elétrica & $3,2 \%$ & $0,2 \%$ \\
Sem tratamento de esgoto & $31,1 \%$ & $4,1 \%$ \\
Sem coleta de lixo & $15,2 \%$ & $1,8 \%$ \\
Sem telefone & $34,6 \%$ & $9,0 \%$ \\
\hline
\end{tabular}

Fonte: Pesquisa Nacional por Amostra de Domicílios (IBGE, 2005).

A incidência de analfabetismo no Brasil ainda é de $10,5 \%$ e no DF cai para 5\%. Na área dos registros civis, em 2004, a média nacional de registros tardios (registros de nascimento lavrados após três meses do nascimento e acompanhados ano a ano pelo IBGE, até 10 anos ou mais) foi $15,1 \%$, caindo para 13,5, em 2005; no DF, $5 \%$ e 4,7\%, respectivamente (IBGE, 2004, 2006). Em 2004, a média brasileira de sub-registro de nascimento foi $16,4 \%$, caindo para 11,5\% em 2005; a incidência no Distrito Federal foi a mais baixa do País: 0,6\% e -1,8\% (IBGE, 2004, 2006). 
Ligado ao fenômeno do não-reconhecimento paterno, persiste o problema do sub-registro de nascimentos - conjunto de pequenas cidadãs e de pequenos cidadãos que vivem à margem, destituídos de Registro de Nascimento. O não-reconhecimento aí se oculta: parte desse universo de crianças permanece indocumentada porque as mães esperam que os pais se disponham a reconhecê-las. ${ }^{12}$

Diversos setores da sociedade e do governo têm encaminhado iniciativas facilitando o acesso ao Registro Civil de Nascimento, entretanto não tive oportunidade de observar o estabelecimento de qualquer relação entre o sub-registro e o não-reconhecimento paterno. Mantém-se silêncio em torno do tema, possibilitando legitimar-se culturalmente a reatualização de práticas de velhos patriarcas por uma legião de homens que não reconhecem as crianças que engendram.

Uma das principais características do patriarca é o poder arbitrário e discricionário de reconhecer ou de recusar filhas e filhos, exercendo, por essa via, o controle de sua reprodução, assim anunciado por Weber, na Sociologia da dominação:

... los niños se distinguieron, en cuanto sometidos libres, de los esclavos. El capricho del dominus determinaba, ciertamente, la pared divisoria. Sólo él podía decidir quien era su hijo. Según el derecho romano (...) podía convertir por testamento a seus esclavos en herederos, así como vender su hijo como esclavo. (Weber, 1944, p. 754).

A deserção da paternidade manifesta a persistência desse poder, uma cláusula pétrea do patriarcalismo. $\mathrm{O}$ aumento do número de crianças nascidas fora do casamento coloca para a sociedade o dilema de criar novos horizontes para a paternidade ou de preservar, indefinidamente, as possibilidades reais de reatualização desse poder, exercido no domínio das questões de filiação, com crianças nascidas fora do casamento mantidas com a possibilidade real de serem filhas da mãe, em um quadro em que nem elas, nem as mães contam com a solidariedade nem dos pais, nem do Estado brasileiro. O estabelecimento da filiação paterna - na legislação e na cultura 
patriarcal fortemente vinculado à vontade, ao arbítrio do pai - ainda está garantido somente a crianças filhas do marido da mãe. Em outras palavras, o casamento e, por conseqüência, a família tradicional são preservados como territórios privilegiados de nascimentos e a igualdade real entre todas as nossas crianças mantém-se como um horizonte a perseguir. A incidência de não-reconhecimento paterno no Brasil expressa a resistência cultural e legal em superarmos o heteropatriarcalismo.

\section{Novas leis, velhas resistências}

A análise da realidade na qual se inscreve o não-reconhecimento paterno indica a persistência da hegemonia conferida ao marido da mãe e às práticas patriarcais no tratamento de meninas $\mathrm{e}$ meninos ${ }^{13}$ concebidos e nascidos fora do casamento - em relações eventuais, em relações estáveis. Novas prescrições legais e mesmo constitucionais estabelecendo a igualdade entre todas(os) as(os) filhas(os) têm se revelado insuficientes para erradicar a desigualdade real entre as crianças (Thurler, 2003). Em 1988, a Constituição do país anunciou: "Os filhos havidos ou não da relação de casamento, ou por adoção, terão os mesmos direitos e qualificações, proibidas quaisquer designações ${ }^{14}$ discriminatórias relativas à filiação" (Artigo 227, parágrafo $6^{\circ}$ ). O Código Civil atual (Lei 10.406, de 10 de janeiro de 2002) reafirma, nesses mesmos termos, a igualdade entre os filhos (Artigo 1.596). Assim, designações como filha ou filho "legítimo", "ilegítimo", "natural", "adotivo" foram abolidas, o que por si só não determinou a abolição das práticas discriminatórias em relação às crianças e às maternidades que continuam mantidas hierarquizadas. Uma forte resistência masculina em abandonar práticas patriarcais leva não poucos homens - pais, não-maridos da mãe - a adotarem medidas protelatórias, relativamente ao reconhecimento de suas crianças.

Apesar de progressos jurídicos recentes - como a aprovação da Lei da União Estável (Lei 9.278, de 10 de maio de 1996) -, a filiação permanece questão inamovível do heteropatriarcado. Mesmo 
no nascimento em união estável, a qualificação jurídica da criança ao nascer depende da vontade intocável do pai. A magnitude do nãoreconhecimento paterno das crianças brasileiras resulta de práticas arbitrárias, em um contexto cultural sexista e misógino, com a predominância de um Direito androcêntrico.

A Constituição de 1988 desconstituiu o casamento como território privilegiado de nascimentos, onde somente nele a criança teria assegurado o reconhecimento pelo pai. Preservada na realidade, a hierarquia entre as mães - casadas e não casadas - e entre as crianças dribla o princípio constitucional de igualdade entre todos os filhos. Interpretações com viés patriarcal privilegiam o direito ao pai para os/as filhos/as do marido da mãe. A resistência a transformações adotou a estratégia de mudar formulações, continuando a nos manter reféns dos dispositivos legais da antiga ordem sociossexual. Uniões estáveis não garantem o direito ao pai, pois, mesmo nesses casos, a mãe não pode fazer a declaração de nascimento estabelecendo a filiação materna e paterna. Destaco aqui o testemunho dado por M. G., auxiliar de enfermagem, 45 anos, de Planaltina, Distrito Federal. Ela é mãe de 4 filhos nascidos de uma mesma relação, sem casamento, que teve com M. V. O mais jovem deles tem 17 anos e vive uma adolescência turbulenta. $O$ pai desses meninos deixou-a durante essa última gravidez. O menino ficou somente com a filiação materna. Ela conta que aos sete anos, o menino percebeu a diferença de sua condição em relação a seus três irmãos. Ele mantém contato com o pai. Pede-lhe há dez anos para reconhecê-lo. O pai faz promessas ao adolescente, cria expectativas e até fixou, algumas vezes, o dia em que iria fazer o reconhecimento. J. L. G. continua, entretanto, diferentemente de seus três irmãos, somente com a filiação materna. O Direito de Família brasileiro, para fins de estabelecimento da filiação paterna, não acena com proteção efetiva nem mesmo às crianças nascidas em relações estáveis, ${ }^{15}$ mantendo-se em desacordo com a Constituição Federal, que prescreve a igualdade entre todas as nossas crianças.

Assim, a igualdade constitucional entre nossas crianças, quanto ao efetivo direito ao pai, convive com desigualdades muito 
reais. Uma legislação ainda androcêntrica, em meio a contradições, em última instância, preserva o velho princípio exposto em nosso primeiro Código Civil, mantido nas entrelinhas do segundo: o pai é o marido da mãe. Brito (2000) argumenta em favor da presunção da paternidade na união estável, deixando ao pai indicado, em caso de discordância, a possibilidade de demonstrar o contrário. Para Pereira (2001) a união estável "não autoriza presumir a paternidade, somente podendo constituir uma prova indicativa ${ }^{16}$ para a investigação da paternidade".

O Direito de Família surgiu com a secularização das relações conjugais e parentais e com o patrimônio associado a essas relações. A autonomização relativamente ao Direito Canônico levou a incorporação da família ao discurso jurídico, como fato social e moral. Ao longo do século XX, a legislação sobre a família revelou grande funcionalidade para preservar uma estrutura cultural, política e economicamente sexuada, assegurando, dialeticamente, a manutenção de padrões não-igualitários nas relações sociais de sexo.

O Código Civil brasileiro de 1916, estabeleceu em matéria de filiação que "o pai é o marido da mãe". E, em seu Artigo 358 , interditou qualquer busca da paternidade. Está já aí contida a presunção de mentira, a destituição de credibilidade de toda mulher fora do casamento. A rigor, sequer a mulher casada estaria a salvo da presunção de mentira, pois ela não poderia declarar não ser o marido, o pai de seu/sua filho/a. O $2^{\circ}$ Código Civil brasileiro - Lei n ${ }^{\circ} 10.406$, de 10 de janeiro de 2002 - explicitou sem constrangimentos, já no século XXI, o que o Código de 1916 havia deixado subentendido: nos Artigos 1.600 e 1.602, estabelece: "Não basta o adultério da mulher, ainda que confessado, para ilidir a presunção legal da paternidade [do marido]" e "Não basta a confissão materna para excluir a paternidade [do marido]". A palavra da mulher não deve ser legalmente considerada como crível, nem para negar a paternidade, nem para constituí-la. Um Parlamento composto majoritariamente por homens mantém a palavra da mulher esvaziada de sentido tanto para a constituição quanto para a exclusão da paternidade. 
Facchin (2003, p. 139) bem analisa: “... a nova legislação não se preocupou em dar valor jurídico à posição da mulher, permanecendo a ausência de atribuição de sentido à declaração materna “. Desigualmente, no Artigo 1.601, o Código Civil possibilita a desconstrução, pelo homem, de qualquer presunção, estabelecendo que toda paternidade é igualmente contestável, mesmo no interior do casamento. Eis, textualmente, esse artigo: "Cabe ao marido o direito de contestar a paternidade dos filhos nascidos de sua mulher, sendo tal ação imprescritível." Assim, o Código Civil de 2002 ao acabar, unilateralmente, com o princípio de que "o pai é o marido da mulher" - pois somente o pai pode, a qualquer tempo, questionar a paternidade do filho de sua mulher - institui e legitima a possibilidade de práticas não igualitárias entre homens e mulheres, confrontando o princípio de igualdade entre homens e mulheres, constitucionalmente estabelecido. ${ }^{17}$

O Instituto Brasileiro de Direito de Família (IBDFAM) propôs a revogação dos artigos 1.600,1.602 e 1.611 e alteração do artigo 1.601 do Código Civil por "ofensivos à dignidade da mulher", inserindose no jogo dialético, permanente e nada linear, por democratizar as relações sociais entre homens e mulheres. A sugestão do IBDFAM está apresentada para apreciação ao Congresso Nacional no Projeto de Lei $\mathrm{n}^{\mathrm{o}}$ 4.946, proposta pelo deputado Antonio Carlos Biscaia (PT-RJ), em 23 de março de 2005.

No quadro das relações sociais de sexo, MacKinnon (2005) examina como legislações sexuadas, recaindo sobre a vida das mulheres, continuam a pressupor a experiência masculina como normativa, relevante e crível. Bem anteriormente e fora do viés feminista, mas não assexuadamente, Hegel (1941) definia a lei humana, em sua atividade, como virilidade, universalidade e governo. Ainda que admitindo a complexidade da posição de Antígona - que ele retomou em Ésquilo, mas sobretudo em Sófocles - a feminilidade era mesmo o delimitado, a errância na história, representando, sim, a negatividade no jogo dialético. ${ }^{18}$ Uma negatividade estéril, entretanto, pois se manteria distante do desenvolvimento do Espírito no Estado. 
Assim, mesmo após mudanças progressistas relativamente à filiação, milhões de crianças e adolescentes continuam sem se beneficiar dessas mudanças, pois muitos homens as ignoram ou lhes opõem forte resistência, adotando práticas de filiação ligadas à cultura patriarcal, apoiadas em normas sexistas e misóginas - em geral não escritas, mas, algumas vezes, expressamente escritas, como no caso do Código Civil de 2002, nos Artigos 1.600, 1.601 e 1.602 .

A Lei da Paternidade (Lei $n^{\circ} 8560$ ) foi aprovada em 29 de dezembro de 1992, para os filhos de casais não casados - vivendo uma relação eventual ou convivendo em união estável. Dois aspectos dessa lei são relevantes. Em primeiro lugar, ela reconheceu à mãe não casada com o pai, a condição de cidadã com o direito de declarar, na oportunidade da lavratura do registro de nascimento, ainda que em separado, o nome do pai. Ao lado desse ganho, há a realidade de muitas mulheres desconhecendo esse direito e de outras sofrendo ameaças para não indicarem o nome do pai. Por outro lado, essa lei redimensionou a paternidade, promovendo seu deslocamento da esfera privada para a condição de questão de interesse público. $\mathrm{O}$ Direito propôs a transição do indivíduo-pai, para o pai-cidadão, pois a paternidade se realiza na pólis. Com isso, o Ministério Público passou a deter poder para propor ação de investigação da paternidade em nome próprio ou da criança.

Recentemente, uma ação de investigação da paternidade, envolvendo concepção e nascimento em relação eventual, chegou pela primeira vez a uma das mais altas Cortes de Justiça do País. Uma decisão inovadora do Supremo Tribunal de Justiça (STJ) foi provocada com o voto da ministra Nancy Andrighi. A ministra argumentou que padrões sociais e comportamentais contemporâneos vêm dissociando vivência da sexualidade e envolvimento afetivo. Uma relação eventual pode, sim, garantir uma concepção. Além de promover a igualdade de responsabilidade reprodutiva entre mulheres e homens, em relações estáveis ou não, a decisão inédita promove a igualdade entre todas/os as/os filhas/os - nascidos em relações estáveis ou fugazes, no casamento ou fora dele. O STJ 
considerou procedente a ação do menino L. F. da S. L., representado por sua mãe E. da S. L., determinando ao Cartório, em Porto Velho (RO), a inclusão da filiação paterna no registro de nascimento do menino. ${ }^{19}$

Frátrias marcadas pela desigualdade e pela exclusão, envolvendo filhas/os tidos no casamento e fora dele - muitas vezes articulando opressões de sexo, de classe e de raça - tornam visíveis não só os limites das leis, as tensões presentes nos processos de produção e aplicação das leis, mas também tornam visíveis a resistência dos homens à constituição de frátrias igualitárias e à adoção de práticas cidadãs de paternidade.

\section{Outros horizontes: promoção dos direitos reprodutivos}

A possibilidade de outros horizontes para a paternidade e para a parentalidade no masculino e no feminino demanda universalização dos direitos reprodutivos, com políticas de reconhecimento da autonomia das mulheres em questões de procriação, e superação da misoginia e do sexismo, que se expressam, privilegiadamente, no controle da sexualidade das mulheres. Aragão (1994, p. 61) assim se refere a esse controle sobre as mulheres: "O xingamento maior em nossa sociedade ainda não é 'corrupto', 'preguiçoso' ou 'sacripanta' (...) mas o nosso velho conhecido 'filho da p...'. O que significa isso? Significa, entre outras coisas, que ainda temos problemas com o obsessivo controle da sexualidade feminina".

Nas culturas patriarcais, o controle da sexualidade torna-se um dos mecanismos mais importantes para subordinar mentes e corpos das mulheres. Analisando a questão da violência associada à sexualidade, Suárez, Machado e Bandeira (1999, p. 307), registram: "o controle se traduz em direitos que os maridos/companheiros exercem sobre suas esposas/companheiras (...) Assim, a violência insere-se no plano da ordem, do prenunciado e do prescrito. Trata-se de um fato sociológico, ou seja, do modo como as relações sociais, expressando valores, definem a distribuição de poder, prestígio e 
legitimidade que organizam os laços entre homens e mulheres e, somados a outros critérios de classificação social, são os responsáveis, em boa parte, pelo fenômeno da violência". Uma expressão de violência contra as mulheres é o exercício do direito à punição pela vivência da sexualidade fora da condição de reprodutora de filhos e filhas legítimos, com o não-reconhecimento paterno de tais crianças, no plano da ordem, do prenunciado, do prescrito.

A divisão sexual do poder e do trabalho, transversalmente presente na sociedade, reparte e organiza o poder entre os sexos, segundo os interesses e as necessidades do dominante, operando um processo de categorizações sexuadas, fixando definições sociais, como o que é considerado normal para a mulher, o que é socialmente aceitável (Devreux, 2005). Na dinâmica da produção de categorias sexuadas se insere a questão do reconhecimento e do comprometimento paterno que flexibiliza leis, conforme os interesses do dominante.

O controle da sexualidade das mulheres se exerce, privilegiadamente, no campo das questões reprodutivas - contracepção, aborto, esterilização -, colocando-se aí as possibilidades e os limites de um efetivo reconhecimento da liberdade reprodutiva e da promoção dos direitos reprodutivos das mulheres.

O Brasil tem tido dificuldades em universalizar os direitos reprodutivos, a igualdade de acesso a informações e métodos contraceptivos. O Ministério da Saúde desenvolveu ampla pesquisa sobre atenção à saúde das mulheres atendidas pelo Sistema Único de Saúde (SUS), com dados colhidos junto a 5.255 municípios, entre outubro de 2003 e abril de 2004. Pouco mais da metade deles $(54,1 \%)$ declararam atender a mais de $75 \%$ da demanda por atendimento em planejamento familiar. $\mathrm{O}$ não-atendimento da demanda por planejamento familiar apresenta a mais alta incidência entre municípios da Região Norte $(8,5 \%)$ e Sudeste $(8,3 \%)$. Entre mais de $90 \%$ dos municípios, a oferta de contraceptivos concentrase na pílula ( $47,2 \%$ deles) e no preservativo masculino ( $53 \%$ deles), ambos atendendo acima de $75 \%$ da demanda. Costa (2004) alerta 
para a necessidade de atenção especial para o caso do condom masculino, pois o Programa de Prevenção à AIDS certamente mudou comportamentos e impactou sobre esses resultados. A avaliação apresentada pela pesquisadora é de que “...Quanto à organização da atenção prestada às mulheres, ainda há um longo caminho a percorrer para que seja possível garantir-lhes informações e tecnologias para o exercício de suas escolhas reprodutivas autônomas. Por enquanto, a autonomia decisória das mulheres é refém da oferta de serviços e de métodos contraceptivos" (Costa, 2004, p. 145).

No Brasil, graças a uma legislação arcaica, votada maciçamente por homens, ${ }^{20} \mathrm{o}$ aborto ainda é ilegal, inseguro e criminalizado, penalizando mais duramente o segmento de mulheres pobres. ${ }^{21} \mathrm{~A}$ Rede Nacional Feminista de Saúde e Direitos Reprodutivos estimou a realização de 750.000 a 1.400 .000 abortos clandestinos no País no ano de 2000, "considerando apenas os dados de internação do SUS" (RedeSaúde, 2001, p. 50).

A esterilização feminina revela a realidade perversa de mulheres sofrendo controle de sua sexualidade e, ao mesmo tempo, serem deixadas sós para gerir a contracepção e a procriação. Por que mulheres brasileiras recorrem à esterilização? O recurso à esterilização utilizado pelas mulheres revela um elemento comum, para além de sua classe social: na dinâmica das relações sociais de sexo, a gestão da reprodução fica com elas, não só no âmbito do casal, mas, mais amplamente, no âmbito da família e da própria comunidade. "O ponto de vista e o comportamento do parceiro tem, com efeito, influência na decisão de se esterilizar. Essa decisão é freqüentemente uma escolha de autonomia na gestão de sua capacidade reprodutiva diante das dificuldades de compartilhar a responsabilidade com o parceiro" (Corossacz, 2004, p. 63).

\section{Outros horizontes: atribuição de valor à palavra da mulher}

A trajetória da produção e implementação de leis tem ambigüidades expressas nos próprios conteúdos, nas tensões entre 
avanços admitidos e conseqüências contraditórias que provocam. É o caso da determinação da paternidade mediante exame em DNA, com alta confiabilidade graças ao desenvolvimento da pesquisa genética.

Por um lado, o advento desse exame representou um avanço, pois anteriormente a mãe solteira tinha que provar à Justiça ser "mulher virtuosa" - o que se constituía em uma empreitada jurídica nada fácil para mulheres que, ao gerar um filho fora do casamento, já haviam adotado um comportamento dissidente que, por si só, as "desqualificava" social e juridicamente. Assim, o advento do exame em DNA tornou possível o deslocamento do julgamento da moralidade da mulher para um apelo ao recurso da ciência.

Há mais de trinta anos, o Código de Processo Civil estabeleceu que ninguém pode obstruir os trabalhos da Justiça. ${ }^{22}$ Uma exceção, entretanto, é admitida na prática, se superpondo à lei: nos processos de investigação da paternidade, homens indicados como pais, ainda se recusam a fazer o teste em DNA, ocasionando uma obstrução real ao trabalho da Justiça. As desigualdades nas relações sociais de sexo, na produção e aplicação das leis estão aqui muito presentes. As mulheres sofrem uma dupla discriminação. As leis brasileiras estabelecem que o ônus da prova da paternidade deve recair sobre elas. Em contrapartida, os homens lutam em todas as instâncias para manter uma contradição que, parece, lhes seria "vantajosa" na aplicação da lei: mantêm-se exigindo das mulheres a "prova" da paternidade e, ao mesmo tempo, se reservando o "direito" de não produzir essa "prova".

Por outro lado, o fenômeno da sacralização e da disseminação dos exames em DNA, no Brasil, tem contribuído para reforçar hierarquias e desigualdades nas relações sociais de sexo, mediante um duplo mecanismo: multiplica-se a "dúvida" quanto à paternidade e "legitima-se" o sentimento do "direito" a uma "prova". Ao mesmo tempo, a palavra da mulher torna-se mais e mais enfraquecida e sua veracidade, mais e mais posta em questão. Nessa linha se situa o posicionamento do geneticista, ao declarar: "a única maneira 
realmente eficaz de se comprovar a paternidade é através da perícia técnica, mais especificamente, pelos exames em DNA" (Pena, 1997).

Em intervenção no I Congresso de Direito de Família do Mercosul, Fonseca (2004) relata o caso de Elói que, mesmo mantendo relação estável de 15 anos, e tendo três filhos desse relacionamento, declarou não os haver reconhecido por não ter "certeza" da paternidade. É interessante que, apesar de ouvir testemunhas e receber ampla prova da convivência conjugal desse homem com a mãe das crianças, o juiz ainda exigiu uma "prova contundente" (isto é, o exame em DNA) antes de declará-lo pai delas. (...) Existe uma aceitação tácita da "normalidade" de o homem exigir esse "direito", deixando a ciência decidir os fatos, antes de ele assumir um compromisso tão sério. ${ }^{23}$ As autoridades vêm confirmando a aliança lei-ciência e reafirmando, no campo das relações sociais de sexo, o poder masculino em demandar "provas" - não raras vezes, ao mesmo tempo, colocando, obstáculos a que essas provas sejam produzidas -, confirmando e reproduzindo o entendimento misógino da mentira presumida das mulheres sobre a paternidade de suas crianças. Em maio de 2004, em Brazlândia (DF), um homem indicado como pai de uma criança com sete anos, em audiência com as Promotoras de Justiça que lá implementavam o projeto Pai Legal nas Escolas, consultado sobre a razão porque não havia reconhecido a menina, respondeu: “...não reconheci porque tinha $1 \%$ de dúvida...” Ele tinha $99 \%$ de certeza, mas não exercitou a solidariedade durante sete anos, nem com a mãe, nem com a menina... pois tinha $1 \%$ de dúvida.

Mudanças tecnológicas sofisticadas - como o caso da emergência dos exames em DNA - podem provocar novos mecanismos de resistência a transformações substantivas. Uma ruptura no quadro da paternidade e da filiação somente acontecerá com o deslocamento do eixo do problema da mentira presumida para a presunção de verdade da palavra da mulher. Mas o que significa a presunção de verdade da palavra da mulher em matéria 
de procriação, para além da instituição do casamento e dos exames em DNA?

Apollon (2000, p. 119) nos conduz à reflexão em torno de uma ética da masculinidade. "Que é um pai, qualquer que seja a cultura ou a época? Um pai é um puro dom de uma mulher a uma criança. Mas é, também, um puro dom de um homem a uma mulher".

O papel e o lugar do pai, sua significação é o de preservar a dimensão do crível no coração mesmo das relações das crianças com os pais, das crianças entre si e dos pais entre eles. A paternidade repousa sobre a palavra da mulher a um homem que, ao mesmo tempo, é a palavra da mulher a uma criança e a palavra da mulher à sociedade. Ainda retomando Apollon (2000, p. 119):

É somente essa palavra que institui para a criança essa relação singular a um homem como seu pai, desde o nascimento e até mesmo antes. E a ética que sustenta a boa-fé dessa palavra - contra toda verificação em busca de garantia - não pode jamais ser colocada em questão sem conseqüências graves para a criança, para a mãe e para o pai .

Com a opção de fazer exame em DNA, esvazia-se de sentido a palavra da mulher de instituinte da paternidade, validadora mesmo da maternidade: "A posição ética que se espera do homem é que ele creia nessa palavra, suportando a ausência de garantia diante da sociedade e pela criança. (...) A busca de garantia significa colocar em questão a palavra da mulher “(Apollon, 2000, p. 121).

Na contribuição de Tahon (2000, p. 148) é a palavra do pai que transcenderia a incerteza. Em sociedades em que não há interditos à interrupção da gravidez, a palavra de consentimento pertence também à mulher (na França, "um filho se eu quiser, quando eu quiser”). O pai é co-partícipe da criação "para que a mulher não seja tragada pela maternidade".

$\mathrm{Na}$ atribuição de valor à palavra da mulher ${ }^{24}$ reside a subversão, a verdadeira transformação. Verucci $(2002$, p. 93) situa essa questão no âmbito dos Direitos Humanos das Mulheres: conferir à mãe o 
direito de indicar quem é o pai de seu filho, eliminar "o princípio da mentira presumida que sempre vigorou na lei e na jurisprudência". A adoção da presunção de verdade na palavra da mulher coloca o imperativo da inversão do ônus da prova.

O Brasil não será original adotando a inversão do ônus da prova. No âmbito internacional, o Conselho da União Européia aprovou, ainda em 15 de dezembro de 1997, a Diretiva 97/80/CE, relativa a casos de discriminação baseada em sexo, estabelecendo a inversão do ônus da prova. ${ }^{25} \mathrm{O}$ Tribunal de Justiça da Comunidade Européia declarou que se impõe a adaptação das regras do ônus da prova em caso de presumível discriminação, casos em que a aplicação efetiva do princípio da igualdade de tratamento exige que o ônus da prova incumba à parte demandada.

$\mathrm{Na}$ América Latina, em 8 de janeiro de 2005, com a Lei 28.457, o Peru regulamentou a filiação judicial de paternidade extramatrimonial: é apresentada a demanda diante do Juiz, que expedirá uma resolução declarando a paternidade. ${ }^{26}$ Se o pai indicado discordar, terá dez dias para contestar, submetendo-se a exame em DNA (Varsi Rospigliosi, [s.d.]). Em Cuba, o Código da Família, de 14 de fevereiro de 1975, propõe o procedimento da inscrição do nascimento feita pela mãe, limitando o prazo da manifestação do pai para 30 dias. Em caso de não-comparecimento, a paternidade lhe é atribuída. Ao homem indicado pela mãe será concedido ainda o prazo de um ano para impugnar o registro e provar não ser o pai (Verucci, 2002).

\section{Outros horizontes: de práticas patriarcais ao exercício cidadão da paternidade}

A passagem de um exercício patriarcal para um exercício contemporâneo e cidadão da paternidade não é, certamente, processo simples. Uma das propriedades-chave das relações sociais de sexo/ gênero é a transversalidade, significando que sua lógica transborda por toda a sociedade, articulando campos como trabalho produtivo 
e reprodutivo, trabalho profissional e família, política e trabalho. Assim, as questões da paternidade - patriarcal ou cidadã, arbitrária ou solidária - não se colocam isoladamente.

No campo das leis, diria que essa trajetória se iniciou com a criação do Registro Civil de Nascimento, quando o País - no ano que antecedeu a proclamação da República - buscou a condição de Estado laico. A história da construção da paternidade cidadã se confunde com a história do Brasil republicano. Desde então, entre tensões, em um caminho tortuoso, as leis têm mudado, não significando sempre efetivo avanço. As dificuldades se multiplicam na aplicação da lei diante de flexibilidades - em um jogo político tensionado, entre progressos e recuos - admitidas nas interpretações das leis.

Resistências à efetivação das leis escritas emergem, em parte, pelo embate com normas não escritas, presididas por uma lógica que preserva a desigualdade e a hierarquia nas relações sociais entre mulheres e homens, entre crianças tidas no casamento e fora do casamento, a divisão sexual do trabalho parental. Coloca-se o problema de a evolução do direito ser acompanhada por mudanças nas representações sociais, no quadro das relações parentais.

Entre 2002 e 2004 tive a oportunidade e o privilégio de acompanhar inciativas do Ministério Público no Estado da Bahia e no Distrito Federal, envolvendo 2.238 estudantes de 7 a 14 anos sem reconhecimento paterno, em 63 escolas da rede pública de ensino. Nesse universo de estudantes somente com a filiação materna estabelecida, 648 entre eles (29\%), após um enorme trabalho desenvolvido por Promotoras de Justiça, ${ }^{27}$ conseguiram o reconhecimento do pai.

É no quadro de resistências de toda ordem que a questão do reconhecimento - aqui do reconhecimento paterno formal e social-afetivo - associa-se inalienavelmente às lutas políticas por promoção dos Direitos Humanos e pela reinvenção e radicalização da democracia. 
O reconhecimento paterno promove a igualdade na frátria, certamente erodindo práticas patriarcais, favorecendo o aprofundamento da democracia e a abertura de espaços para novas formas de relações parentais, como a homoparentalidade e a pluriparentalidade.

\section{Notas}

1 Ver Silva e Pereira, "Nem só de pão vive o homem", neste Dossiê.

2 Ou, como reflete Benjamin (2004), poderíamos pensar, sem nostalgias, em um patriarcado sem pai, desenvolvendo as intuições da teoria crítica sobre o caráter mutante da dominação.

3 Refiro-me a Axel Honneth e seu livro publicado em 2000, com esse título (Das andere der Gerichtigkeit, Frankfurt, Suhrkamp).

4 Somente $10 \%$ dessas pessoas obtiveram o reconhecimento paterno posteriormente.

5 Esquecido pelo pai no carro, bebê morre. Folha de São Paulo, Caderno Cotidiano, 14 abr. 2006.

6 Criança morre asfixiada dentro de carro. Folha de São Paulo, $1^{\circ}$ jun. 2000

7 Ribeirão teve caso igual em 97. Folha de São Paulo, Caderno Folha de Ribeirão, $1^{\circ}$ jun. 2000.

8 Em 14 de dezembro de 2006, a polícia encontrou, no estacionamento de um shopping no Rio de Janeiro, um bebê de quatro meses em um Jeep Cherokee blindado, com ar condicionado ligado. A tia, vinte minutos depois, explicou aos policiais que tinha ido trocar um presente. $\mathrm{Na}$ delegacia, declarou que passara mal e fora ao banheiro. Ela foi indiciada por abandono de incapaz, pagou fiança e responde a processo em liberdade. Se condenada, pode pegar até três anos de prisão (Correio Braziliense, 14.12.06, p. 12). A mídia repercutiu amplamente o caso de Daniele Toledo do Prado, 21, acusada injustamente pela morte da filha, Victória, de um ano e três meses, em Taubaté (SP), em 29.10.2006, por suposta ingestão de cocaína na mamadeira. Daniele foi imediatamente encarcerada. Durante os quatro últimos meses de vida da menina, mãe e filha viveram entre idas e vindas ao Hospital Universitário de 
Taubaté. Daniele sofreu violência sexual no hospital e espancamento na prisão. A menina sofria de vasculite cerebral. Não tive oportunidade de verificar qualquer referência ao pai da menina Victória, em nenhuma das matérias publicadas a que tive acesso. Como se nas representações sociais veiculadas pela mídia, a ausência paterna fosse prevista, esperada, "normal" (Entre outras matérias Folha de São Paulo, 6, 7 e 10 dez. 2006; 16 jan. 2007; Correio Braziliense, 16 jan. 2007).

9 Eis algumas dessas manifestações. "Somente quando for totalmente contra a lei causar danos físicos ou morais à criança, este país vai começar a se desenvolver de verdade. Até lá vamos continuar nesta cultura de irresponsabilidade, onde todos os acidentes nada mais são do que uma fatalidade. (...) Porém num país, onde as pessoas se preocupam mais com os sentimentos do pai "esquecido" do que com o menino que morreu torturado pelas queimaduras do calor excessivo, a infância realmente não é levada a sério. Fatalidade = Irresponsabilidade.” (leitora de Porto Alegre, 14 de Abril de 2006 - 23h42); "Lendo que o pai chorava desesperado e comoveu até os policiais não pude deixar de lembrar de "O estrangeiro", de Camus, em que, no julgamento do protagonista, pesou muito o fato dele não ter chorado no enterro da mãe. Agora me parece, no mínimo estranho, que o choro de desespero tenha livrado o pai da prisão. Esquecer um bebê dentro de um carro... não é o mesmo que esquecer de pagar uma conta ou de dar um telefonema. É um caso estranhíssimo e merece séria investigação ... livre de sentimentalismo" (leitora de Belo Horizonte, 14 de abril de 2006 - 20h53). Pai esquece filho no carro e bebê morre queimado de sol. O Estado de São Paulo. Site acessado em 20 de abril de 2006: http://www.estadao.com.br/ ultimas/cidades/noticias/2006/abr/13/235.htm.

10 No universo dos alunos/as matriculados/as na rede pública de ensino trabalhado pelo Ministério Público do Distrito Federal e Territórios com o projeto Pai Legal nas Escolas, esses números, foram confirmados com pequena oscilação. Em Brazlândia (DF), a incidência foi de $9 \%$ de não reconhecimento paterno - em 15.134 matrículas, 1.348 crianças somente com a filiação materna. No Paranoá, 13,4\% - em 13.657 matrículas, 1.826 alunos/as.

11 No Brasil, entre 2000 e 2005, foram lavrados 21.963 .925 registros civis de nascimento (IBGE, 2001 a 2006). Admitindo-se um índice de 20\% de negação de reconhecimento paterno, seriam 4,3 milhões de crianças somente com a filiação materna estabelecida em seus registros (média 
anual de 732 mil crianças). Se adotarmos um índice de $25 \%$, seriam 5,4 milhões de crianças (média anual de 915 mil crianças), no século XXI, ficando somente com a filiação materna estabelecida. A maioria delas, inteiramente expostas ao arbítrio masculino.

12 A presidenta da Associação Pernambucana das Mães Solteiras, Marli Márcia da Silva, ligada à entidade desde sua criação há 14 anos, em entrevista que me concedeu em junho de 2004, relatou haver conhecido, ao longo desse tempo, diversos casos de mães em tal situação. Igualmente, em agosto de 2005, Jaime de Alencar Araripe Júnior, então presidente da Associação Nacional dos Registradores de Pessoas Naturais (Arpen Brasil), declarou ser a falta de reconhecimento de paternidade um dos fatores que mais agrava o sub-registro de nascimentos no Brasil (Razzak, 2005).

13 Não obstante termos mais nascimentos de meninos, o exame dos Registros Civis de nascimento indicou mais meninas não reconhecidas em oito dos dez Cartórios examinados (Thurler, 2004, p. 82). Destaco também que entre $1^{\circ}$ de janeiro de 1998 e 30 de junho de 1999, o número de bebês abandonados, noticiados nos dois jornais de circulação diária do Distrito Federal, foram onze do sexo feminino, seis do sexo masculino e um cujo sexo não foi identificado (Thurler, 2002).

14 Ênfase minha.

15 Em agosto de 2006, no desenvolvimento do projeto Paternidade e Cidadania nas Escolas, no Estado do Piauí, uma professora da rede pública pedia para ser incluída no projeto. Contou: ela e seus oito irmãos, todos filhos de uma mesma união estável não matrimonializada, não têm o reconhecimento paterno.

16 Grifos meus.

17 "Homens e mulheres são iguais em direitos e obrigações" (Artigo 5', inciso I).

18 Especialmente na Fenomenologia do Espírito, mas também na Filosofia do Direito.

19 O acórdão foi publicado no Diário da Justiça de 3 de outubro de 2005.

20 A democracia representativa - na qual as mulheres estão precariamente incluídas - tem preservado o sexismo, com o grupo dos homens da sociedade continuando a exercer tutela sobre o grupo das mulheres, 
decidindo sobre seus direitos de cidadania. Mecanismos legislativos e jurídicos naturalizam e legitimam essa tutela, mantendo-se uma democracia problemática, mutilada, desde a perspectiva das relações sociais de sexo. Na Câmara dos Deputados, $8,9 \%$ das 513 cadeiras serão ocupadas por mulheres, na legislatura a ser iniciada em $1^{\circ}$ de janeiro de 2007 (46 deputadas). No Senado Federal, entre 81 senadores, serão 12 parlamentares mulheres: $14,8 \%$. No Congresso Nacional brasileiro (594 parlamentares), as 58 mulheres não chegam a um décimo de seus integrantes - apenas $9,7 \%$.

21 Ainda que sejam poucas as mulheres processadas por aborto, levantamento feito pela organização não-governamental Advocacy nas comarcas no Estado do Rio de Janeiro encontrou onze casos, entre 1998 e 2004: mulheres pobres, com baixa escolaridade, negras e solteiras (Raras, ações por aborto só atingem pobres. Folha de São Paulo, Caderno Cotidiano, 6 nov. 2006).

22 O Código de Processo Civil, de 1973, estabelece, textualmente, em seu Artigo 339: "Ninguém se exime do dever de colaborar com o Poder Judiciário para o descobrimento da verdade".

23 É contundente a recente ocorrência em Brasília (DF), envolvendo Antônio Aurélio Gonçalves de Souza, 21 anos, assassinado por um vizinho em 23 de novembro de 2006. Atingido, ele ainda pediu para ser poupado, pois seria pai: em uma semana nasceria sua filha Júlia. O IML teria precisado de um tempo a mais para liberar o corpo para a família, pois teriam sido adotados os procedimentos para teste em DNA para comprovar sua paternidade. Nada valeu o testemunho da vizinhança e familiares que acompanharam o relacionamento do casal e a alegria de Antonio com a perspectiva da chegada de sua primeira filha (Rebello, 2006). Esses e outros casos que podem ser evocados parecem indicar que o exame em DNA vem sofrendo um deslizamento da condição de alternativa de prova para uma imposição pelo Direito sexuado brasileiro. Sem neutralidade, esse mecanismo fortalece o princípio misógino da mentira presumida das mulheres quanto à paternidade das crianças em nosso país.

24 "A palavra da mulher é sagrada como a terra" foi a chamada adotada na

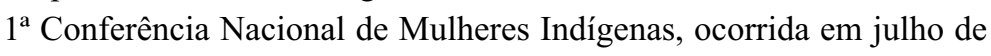
2004, em Brasília. 
25 Site www.europa.eu.int/scadplus/leg/fr/cha/c10913.htm, visitado em 28 de agosto de 2004.

26 Ver artigo de Varsi Rospigliosi, neste Dossiê.

27 Refiro-me às Promotoras de Justiça Hortência Gomes Pinho, do MPBA, e Leonora Brandão Mascarenhas Passos Pinheiro e Renata Salles Moreira Borges, do MPDFT.

\section{D'autres horizons pour la paternité au Brésil} dans le Siècle XXI?

Résumé: Cet article a pour but d'analyser la paternité, en tant qu'exercice e reconnaissance générationnelle, dont les dimensions formelle-légale et affective-sociale sont d'importance égale, dimensions qui dirigent vers le père-citoyen des attentes politiques, ce qui a pour finalité d'approfondir la démocratie. À chacun de ces deux niveaux, l'absence de reconnaissance paternelle pour certains enfants brésiliens est interprétée ici comme la persistance de vieilles pratiques patriarcales, dans lesquelles l'arbitraire masculin était perçu - et reste perçu - comme naturel. Venir à bout de ces rapports sociaux de type patriarcal est un impératif tant pour rendre effectif un droit égal pour tous les enfants d'obtenir la reconnaissance de leur père - qu'ils soient le fruit de relations passagères ou stables, à l'intérieur ou hors du mariage - que pour développer la solidarité, promotrice à la fois de l'égalité des responsabilités et des droits entre hommes et femmes en ce qui concerne la parentalité, et de l'ouverture vers de nouveaux espaces et de nouveaux modes de vie parentaux, tels que la pluriparentalité et l'homoparentalité.

Mots-clés: reconnaissance, paternité, citoyenneté, pratiques paternelles.

\section{Referências bibliográficas}

APOLLON, Willy. La question du père. In: TAHON, Marie-Blanche; CÔTÉ, Denyse (dir.). Famille et fragmentation. Ottawa: Les Presses de l'Université d'Ottawa. 2000. p. 115-125. 
ARAGÃO, Luiz Tarlei de. O casamento acabou, viva o casamento. In: CALLIGARIS, Contardo (Org.) O laço conjugal. Porto Alegre: Artes e Ofícios, 1994. p. 49-64.

BENJAMIN, Jessica. Retour sur l'autorité et la famille ou: um monde sans père? Tumultes, n. 23, p. 185-218, nov. 2004.

BRITO, Nágila Maria Sales. Presunção da paternidade no casamento e na união estável. In: CONGRESSO BRASILEIRO DE DIREITO DE FAMÍLIA, 2, 2000, Belo Horizonte. A família na travessia do milênio: anais do... Belo Horizonte: IBDFAM/OAB-MG, 2000. p. 551-567.

COROSSACZ Valeria Ribeiro. Identité nationale et procréation au Brésil: sexe, classe, race et stérilisation féminine. Paris: L'Harmattan, 2004.

COSTA, Ana Maria. Atenção integral à saúde das mulheres: quo vadis? Uma avaliação da integralidade na atenção à saúde das mulheres no Brasil. Tese (Doutorado) - Faculdade de Ciências da Saúde, Universidade de Brasília, 2004.

DEVREUX, Anne-Marie. A teoria das relações sociais de sexo: um quadro de análise sobre a dominação masculina. Sociedade e Estado, Brasília, n. 20, v. 3, p. 561-584, 2005.

FACHIN, Rosana. Do parentesco e da filiação. In: DIAS, Maria Berenice; PEREIRA, Rodrigo da Cunha (Coord.). Direito de Família e o novo Código Civil. 3. ed. Belo Horizonte: Del Rey, 2003. p. 133-150.

FONSECA, Claudia. O impacto do teste de DNA sobre noções de família e filiação no Brasil contemporâneo. Comunicação apresentada no I Congresso de Direito de Família do Mercosul. Porto Alegre (RS), de 2 a 4 de junho de 2004, promovido pelo Instituto Brasileiro de Direito de Família (IBDFAM) e PUC-RS, 2004.

FRASER, Nancy. Justice sociale, redistribution et reconnaissance. Revue $d u$ Mauss, n. 23, p. 151-164, 2004. De la reconnaissance. Don, identité et estime de soi.

. Políticas feministas na era do reconhecimento: uma abordagem bidimensional da justiça de gênero. In: BRUSCHINI, Cristina; UNBEHAUM, Sandra G. (Org.). Gênero, democracia e sociedade brasileira. São Paulo: Fundação Carlos Chagas, Editora 34, 2002. p.59-78. 
FRASER, Nancy; HONNETH, Axel. Redistribution or recognition: a political-philosophical exchange. London: Verso, 2003.

HEGEL, Georg Friedrich. La phénoménologie de l'esprit. T. II. Paris: Aubier-Montaigne, [1807], 1941.

HONNETH, Axel. La théorie de la reconnaissance: une esquisse. Revue du Mauss, n. 23, p. 133-135, 2004. De la reconnaissance. Don, identité et estime de soi.

. Luta por reconhecimento: a gramática moral dos conflitos sociais. São Paulo: Editora 34, 2003.

INSTITUTO BRASILEIRO DE GEOGRAFIA E ESTATÍSTICA. Estatísticas do registro civil 2000 a 2005. Rio de Janeiro: IBGE, 2001 a 2006. v. 27 a 32.

. Pesquisa Nacional por Amostra de Domicílio (PNAD). Rio de Janeiro: IBGE, 2005.

LAZZERI, Christian; CAILLÉ, Alain. La reconnaissance aujourd'hui: enjeux du concept. Revue du Mauss, n. 23, p. 88-115, 2004. De la reconnaissance. Don, identité et estime de soi.

MacKINNON, Catharine A. Women's lives, men's laws. Cambridge: The Belknap Press of Harvard University Press, 2005.

MATTOS, Patrícia Castro. A sociologia política do reconhecimento: as contribuições de Charles Taylor, Axel Honneth e Nancy Fraser. Tese (Doutorado em Sociologia) - Universidade de Brasília, 2004.

MITSCHERLICH, Alexander. Vers la société sans pères: essai de Psychologie Sociale. Trad. Fr. M. Jacob et P. Dibon. Paris: Gallimard, [1963], 1969.

PENA, Sérgio Danilo. O DNA como (única) testemunha em determinação da paternidade. Bioética, n. 5, p. 231-241, 1997.

PEREIRA, Rodrigo da Cunha. Concubinato e união estável. 6. ed. Belo Horizonte: Del Rey, 2001.

RAZZAK, Sâmar. Filhos não reconhecidos passam Dia dos Pais em branco. O Estado do Paraná, 13 ago. 2005.

REBELLO, Pablo. Brincadeira fatal. Correio Braziliense, Brasília, 15 nov. 2006 
REDESAÚDE (Rede Nacional Feminista de Saúde e Direitos Reprodutivos). Saúde da mulher e direitos reprodutivos. Dossiês. Sara Sorrentino, Aborto Inseguro. São Paulo, 2001.

SUÁREZ, Mireya; MACHADO, Lia Zanotta; BANDEIRA, Lourdes Maria. Violência, sexualidade e saúde reprodutiva. In: GALVÃO, Loren; DÍAZ, Juan (Org.). Saúde sexual e reprodutiva no Brasil: dilemas e desafios. São Paulo: Hucitec, Population Council, 1999. p. 277-309.

TAHON, Marie-Blanche. Pour penser la mère: distinguer privé et domestique. In: TAHON, Marie-Blanche; CÔTÉ, Denyse (Dir.). Famille et fragmentation. Ottawa: Les Presses de l'Université d'Ottawa, 2000. p. $127-158$.

THURLER, Ana Liési. Paternidade e deserção: crianças sem reconhecimento, maternidades penalizadas pelo sexismo. Tese (Doutorado em Sociologia) - Universidade de Brasília, 2004.

. Paternité et inégalités dans les rapports parentaux: une analyse de cas brésiliens. Cahiers du Genre, Paris, n. 36, p. 69-88, 2003.

. Novas fogueiras no final do século XX: comportamento da mídia em caso de deserção da maternidade e de deserção da paternidade. Diálogos Possiveis, Revista da Faculdade Social da Bahia, Salvador, Bahia, v. 1, n. Zero, p. 49-68, 2002.

. Mulheres na mídia: fabricação de verdades e violência de gênero. 2001. Disponível em Observatório da Imprensa: $<\mathrm{http}: / /$ observatoriodaimprensa.com.br/artigos/fd130620011.htm>.

VARSI ROSPIGLIOSI, Enrique. El nuevo proceso de filiación: en el nombre del padre. [s. d.]. Disponível em Jus Navigandi.: $<$ http://jus2. uol.com.br/doutrina/texto.asp?id $=6514>$.

VERUCCI, Florisa . O direito de ter pai. In: LEITE, Eduardo de Oliveira. (Org.). Grandes temas da atualidade: DNA como meio de prova da filiação. Rio de Janeiro: Forense, 2002. p. 87-100.

WEBER, Max. Economia y Sociedad: esbozo de sociologia comprensiva. Trad. José Medina Echavaría, Juan Roura Parella, Eduardo García Máynez, Eugenio Ímaz y José Ferrater Mora. México: Fondo de Cultura Econômica, 1944. 